\title{
Zulu Names and Indirect Expression
}

\author{
Noleen S. Turner \\ University of Durbin, Westville
}

\begin{abstract}
In addition to direct reference, Zulu names are often used indirectly, as a means of expressing opinions and concerns, giving warnings, raising suspicions, admonishing or chastizing individuals in a society which discourages direct confrontation. Examples and commentary on children's and animal's names used in this way are given.
\end{abstract}

Giving names to people, things, animals, and places is an important practice in all societies, but in some African societies, in this instance Zulu, it assumes a special significance. Among the Zulu, not only do names serve as useful labels to distinguish one person from another, they may reflect natural or historic events associated with the births of the people they name, and, more to our purposes, they may also express in veiled form opinions, admonitions, and accusations. The names so involved may be given to domestic animals as well as children and they offer insights into "what is going on in society" (Thipa 1994, 2).

Finnegan (1970) summarizes some functions of naming in Africa:

Names often play an indispensable part in oral literature in Africa.... They have...many different interpretations...from the psychological functions of names in providing assurance or 'working out' tension, to their connection with the structure of society, their social function in minimizing friction, or their usefulness either in expressing the self-image of their owner or in providing a means of indirect comment when a direct one is not feasible. (470)

Zulu children (and domestic animals as well) may be given personal names in which an indirect social message is embedded. These names act to release tensions, to deflect criticisms, or to point out lapses or indiscretions in a community where direct confrontation or direct expression is socially unacceptable. The names function, in Suzman's words, as "injunctions towards individuals in the larger society" (1994, 259). Names which function in this way are often directed toward unspecified but particular persons who will identify the messages encoded in them.

Names 48.2 (June 2000):127-137

ISSN:0027-7738

(C) 2000 by The American Name Society 


\section{Names 48.2 (June 2000)}

Koopman $(1986,87)$ notes that one of the reasons for giving particular Zulu names is "friction," referring to "friction at the time of birth, either between the parents, or between parents and in-laws, or between parents and neighbors." Koopman $(1994,24)$ makes the additional point that animal and personal names have dual purposes: to act on the level of denotatum, to label, identify or call a person, dog, or beast, while at the same time acting on the level of designatum, to make social comments. My concern is with the social comments encoded in the names.

Zulu society is community-oriented, and conflict and confrontation within a family or with one's neighbors is of concern to the entire community. Among the Zulu, whether in rural or in urban areas, contact with one's neighbors is an essential part of life; group solidarity and interdependence is of great importance and an individual is part of a community whole and thus has to be in harmony with the values and principles accepted by the community.

Oblique allusion is typical of the speech of most Zulus and allusive language is characteristic of Zulu riddles, praises, lullabies, and poetry. Oblique allusion is found in naming as well.

Derisive naming is common in closed communities and in traditional extended families or clans, since by their very nature these communities invite this type of censure as an alternative to more elaborate expression. In Zulu this is called izibongo nezihasho " "praise" poetry' and it refers to a collection of names and praises of either the common person or of domestic animals. The names and praises are extended into stanza form to give an accumulated history or description of an individual or animal. In certain instances, these 'praises' may deviate from the general intention behind normal izibongo 'praising' and become a satirical expression of censure which exposes the unsatisfactory nature of a person's actions.

Much of African life is built upon the principle of ukuhlonipha 'respect'. In rural areas especially, ukuhlonipha is extremely important in such situations as when a young bride moves into her husband's homestead to live among her in-laws. In her new home the bride has very little status and is under the supervision of her mother-in-law, who subjects her to a number of rigid social and working restrictions. Conflicts are common between the bride and her in-laws, between the bride and other co-wives in polygamous situations, as well as among neighbors and between her and her husband. 
Similar situations in European society do not require the kind of oblique expression that is frequent in Zulu society, since several direct options are available: the matter can be discussed openly, involved parties might avoid each other whenever possible, thus avoiding conflict, or as a last resort, the conflict may be referred to the legal system. Zulu society offers another alternative; the practice of composing derisive names provides an individual with an acceptable but indirect way of airing a conflict or expressing discontent in such a way that it is made public to the community at large, and serves as a reminder of the underlying problem or source of discontent. Thus in a situation where one wishes to make one's neighbors, spouse or in-laws aware of something which is causing a problem, there is a way of letting them know in an acceptable, non-confrontational manner, by calling a child's or animal's name out loud for all to hear, and perhaps repeatedly. Although such satirical naming is done mostly by women, it is not exclusively their domain.

An example of the allusive use of names is provided by Molefe (1992), who cites animal names that are extended into poetry, usually by the owner of the animal. These praises are for the most part positive and are composed to show the affection or appreciation of the owner for the animal. Molefe mentions disciplinary messages that are carried in the names of some animals and offers the instance where a man, while cultivating his fields, might call out to his team of oxen:

Where are you going, Thakathani?

Where are you going, Nquluzomjendevu? (78)

Molefe explains that there are two messages contained in the names given to the oxen which are directed toward certain people in the farmer's local community. In the name Thakathani, which loosely means 'continue bewitching', the farmer is aiming his message at those whom he suspects are bewitching him, informing them that he is aware of what they are doing, but it makes no difference to him.

Nquluzomjendevu means 'hips of the unmarried, middle-aged woman' and the namer is telling his neighbors by calling out the name of this beast loudly in passing, that their daughter should have gotten married a long time ago, as she is getting past the acceptable marriageable age. 


\section{Names 48.2 (June 2000)}

I would like to contribute some additional examples and commentary to the existing literature on Zulu allusive names, as they relate to certain types of domestic conflict.

\section{Friction Between Spouses}

Assigning a name to a child or an animal may serve as an ideal way of expressing the pent up frustration spouses or intimates may feel about something their partner has done; this is an especially attractive option for women, since in traditional Zulu society a wife is not free to directly confront her husband, or argue directly with him.

Nsizwazonke 'all young men'

There is a clever double entendre in this name, which was given to a fourth-born son by his father. Initially the name was taken at face value, meaning that the couple had had only sons, but as time went on, it became apparent that the intention behind the name was to let others know that the husband was aware of his wife's promiscuity with a number of young men in the community.

Mphikeni 'the denial'

This name was given by a child's mother to publicize the father's refusing to accept the fact that the child was his.

Dumazile 'you have disappointed me'

This child was named by her mother to record her disappointment in her marriage. She was taken very much for granted by her husband and she made this fact known through the name of her daughter.

Qondeni 'what is your intention?'

The question in this name was posed to her husband by a wife in order to ascertain his intentions since he sided constantly with his parents in the continual friction between them and his wife.

Maliyavuza 'the money is leaking'

This cow was named by a woman whose husband had won a jackpot at the races. Instead of investing the money wisely, however, the man had spent it on feasting, and buying horses and cattle. Three of the cattle had died, and she named the fourth one in this way to warn her husband against wasting all the money irresponsibly. 
Maliyami 'my money' (continuation of previous)

On purchasing another cow, the man then replied to his wife by naming the new cow 'my money', thus telling her that he would dispose of his money as he saw fit.

Shiy'umuzi 'leave the homestead'

A woman named her dog in this way after her husband had left her for another woman.

Doli 'doll'

This name was given to her cat by a woman who wanted to make her husband aware of the fact that she knew he was having an affair with a woman named Dolly.

Friction Between In-laws

A Zulu bride is the focus of intense scrutiny by her in-laws, particularly by her mother-in-law, and the names given to animals often reflect these particularly difficult relationships.

Hlalezwini 'stick to the word'

This name was given by a father to his first born as a way of supporting his wife against his own parents, who had criticized her for a number of years for being childless. She constantly maintained during this time that she would eventually have a child.

Fikanaye or Zinazo 'arrive with her/him'

This name was given by a mother-in-law to the child born to her daughter-in-law seven months after marrying her son, giving air to her suspicion that the child was illegitimate.

Bhekisisa 'look carefully'

In giving this name to her grandson, a mother-in-law was attempting to draw her son's attention to the fact that his wife was having extramarital affairs, thus casting doubt on the legitimacy of the child.

Nkomozelanga 'cow of the sun'

A daughter's father gave this name to a cow to illustrate his dissatisfaction over the lobolo 'dowry' received. The cattle he had received for his daughter's lobolo were very skinny as if they had been through a severe drought, and the name is aimed at the stinginess of the daughter's husband and his family. 


\section{Names 48.2 (June 2000)}

Zigizendoda 'footsteps of a man'

A bullock was given this name by a mother-in-law to express her opinion of her daughter-in-law's masculine behavior. This girl had taken to running, and on certain occasions during her husband's absence, she would wear a pair of trousers on visits to town, a practice frowned upon by more conservative Zulu men.

Zakhele 'build for yourself'

Dissatisfaction between a family and the new daughter-in-law is revealed in this name, which resulted from the selfish and uncooperative behavior of the new bride. The name contains a warning that if she does not comply with what is expected of her, she will have to move out.

Bayetshwaleni 'they are at the tavern'

A mother-in-law named her dog in this way to criticize her son and his wife because they spent too much time drinking at the local tavern.

\section{Friction Within the Family}

In these examples, the names given to children and animals often reflect problems within a family, likely between siblings or between parents and children.

Mphikeleli 'the stubborn one'

This grandfather named his granddaughter's second child out of wedlock in this way to register his annoyance at the fact that she had not heeded his warning after the birth of her first child.

\section{Valisisa 'close it up tight'}

This name was given by a grandmother on the birth of her daughterin-law's twelfth child. The intention in the message was to urge the daughter-in-law to have herself sterilized at the local clinic, as the family was struggling financially to support all her children.

\section{Zwelikabani 'whose land is this?'}

This name reflects an inheritance dispute among a chief's four sons. The lawful heir (the eldest) was threatened with death by the others if he did not share the inheritance with them. In the midst of the dispute, the eldest brother's wife gave birth to a son which afforded him the opportunity to pose the question to his brothers, underlining the legitimacy of his claim to the land. 
Mkhetheni 'single him out'

The third in a family of four sons directed this name as an accusation towards his parents who had paid lobolo for their other three sons, but did not pay for his lobolo. He had worked on his own and saved enough to pay the necessary bride price, and by naming his son thus, he was able to voice his anger and bitterness at his parents for singling him out unfairly in this matter.

Khuz'umkakho 'reprimand your wife'

This message was directed by the eldest brother in a family to his youngest brother's wife. The name he gave the animal was intended to alert his brother to his wife's gossip-mongering ways.

In another instance this same name was given to an ox by a man whose older brother's wife constantly teased him for not being married. She would complain about having to cook and wash for him when he should have his own wife to do it.

Nkomozombango 'cow of dispute'

This name was given to the only remaining cow left to a woman whose husband had died. After his death the eldest brother took all the cattle for his own, leaving only one for his mother, which she named in this fashion as evidence of her discontent.

Phumuphele 'get out, go away'

A beast was so named by a father to admonish his renegade son, whose illegal activities had become unacceptable to his family. When the son would approach the homestead, the father would call out the beast's name in order to let the son know that he was not welcome.

\section{Thubhobho 'two shillings'}

This name was given by an aunt to her dog to reflect the scornful attitude she had towards her niece, who was known to be practicing prostitution. The name reflects the cheapness of the woman, who was prepared to sleep with a man for such a paltry amount of money.

Salakutshelwa 'the one who refuses to be warned'

A father gave this name to his dog as an admonishment of his son's behavior; the son had refused to listen to his father's advice and had suffered accordingly. The name derives from the proverb isalakutshelwa sibona ngomopho 'the foolish one learns the hard way'. 


\section{Names 48.2 (June 2000)}

Friction with Neighbors or Within the Community

Among the Zulu, peaceful relations with neighbors and other members of the community are regarded as necessary; conflict and antagonism are stumbling blocks to successful co-existence in these communities. Therefore, when a problem exists it must be resolved or at least aired, so that suppressed tensions can be worked through without direct confrontation. Many of the problems and discontent that exist among neighbors arise as a result of accusations or suspicions of witchcraft, as noted in the example provided by Molefe, noted above.

Discord in a community is often made public by the naming of domestic animals, usually cattle or dogs, since these names may be called out loudly over fences and across fields. Personal names also play important roles in expressing discontent. In the examples below we see names carrying succinct messages reflecting problems in the community. The main causes of conflict within communities often concern witchcraft, jealousy, dishonesty, and gossiping or spreading rumors.

Mnukwa 'the suspect'

This child was named by his father, who was suspected by neighbors of practicing witchcraft. By naming his son thus, he was venting his frustration and anger at the suspicions cast on him, as well as attempting to deny them at the same time.

\section{Bhekizitha 'watch out for enemies'}

A father named his son in this way in order to alert certain people in the community that he was aware of their enmity towards him. The unfortunate child was therefore called Bhekizinja 'watch out for the dogs' by those in the community for whose benefit the child had been named, as an insult aimed at the father, implying that he was a coward who had to resort to naming his son as a means of dealing with his suspicions.

Nomacece 'the party-goer'

A woman was known for being present at every gathering or ceremony in her area, often when she had no business being there. So intent was she on being present at all gatherings that she actually went into labor and gave birth at one such meeting, giving rise to the name of her daughter. The daughter grew up following in the footsteps of her 
mother, and she was present whenever a fight broke out, or there was conflict in the area, trying to find out details and gossip. The people in the area would refer to her by another name, Nozindaba 'Nosy Parker'.

Zwelenduna 'the headman's country'

A local induna (headman) had an inflated opinion of his own importance and was laying claim to land that did not belong to him but belonged to the local chief. A member of the community, wishing to expose the man's pompous behavior and put him in his place, named his son in this way to comment on who the land actually belonged to.

Thakathabehleka 'smile while bewitching'

This name, given to a beast, is intended to reveal that someone in the family, who acts in a perfectly innocent fashion, is actually believed to be a sorcerer.

Gedleyihlekisa 'relaxed and laughing', 'two-faced person'

After visiting his local isangoma (diviner) to ascertain the reason for his persistent problems, this man named his dog in this way to let his neighbor know that he suspected the neighbor of being the source of all his problems, due to the information he had gleaned from the diviner.

Thathakonke 'take everything', Thathangozwane 'take with the toe',

Umunwe Okhombayo 'the pointing finger' (= thief).

These names are variations on the theme of dishonesty. Dogs are often named in this manner to bring attention to the fact that someone is suspected of being a thief and warns people to be on the lookout.

Bhusumane 'boesman', 'colored'

This derogatory racial slur was given by an old, retired man to the ugliest and cheekiest of a litter of pups born after he had ceased working for a colored man where he had been employed for nearly 20 years. As an employer, the man was well known in the district for being an aggressive and rude man and the satirical name served as a humorous reminder to the old man of his former employer.

In summing up, I quote Walter Ong $(1988,8)$, who noted that "oral cultures concern themselves with doings, with happenings, not with being as such: they narrativize their own existence and their environment." 


\section{Names 48.2 (June 2000)}

Ong's observation is particularly relevant for the situations in which names operate among the Zulu people, especially those in rural areas, from which the majority of these examples are taken. Naming in this cryptic and often satirical way occurs for at least the following reasons:

1. to express dissatisfaction or vent frustration,

2. to cast suspicion or level accusations at certain people,

3. to ridicule, mock or warn against unacceptable behavior,

4. to challenge those to whom, by virtue of position, normal channels of criticism and censure are closed,

5. to dispute allegations or rumors by informing the community that the namer is well aware of the situation.

Names containing cryptic social messages which may reflect censure, disapproval, and discontent, serve an important social function in that they tend to minimize friction in the communal environment by enabling a person to express an opinion, expose a situation, accuse, ridicule or challenge one or more people in the immediate community, in an indirect yet effective manner and allows contentious comments to be passed in a socially acceptable way through the articulation, sometimes repeatedly and usually pointedly, of either a child's or an animal's name. It should be obvious, of course, that the message which is insinuated in these names, thrives only in its native environment and is embedded in its own specific social logic. Unfamiliarity with the background which motivated the composition of the name would result in the implication recorded in the name also being lost.

\section{References}

Finnegan, Ruth. 1970. Oral Literature in Africa. Oxford: Clarendon P. Koopman, Adrian. 1986. The Social and Literary Aspects of Zulu Personal Names. Unpublished M.A. thesis, University of Natal, Pietermaritzburg. . 1994. "The Socio-Cultural Aspects of Zulu Ox and Dog Names. Nomina Africana 6:1-13.

Molefe, L. 1992. An Analysis of the Praises of Domestic Animals (unpublished M.A. Thesis, Univ. of Natal)

Ong, Walter J. 1988. Orality-Literacy Studies and the Unity of the Human Race. Durban: Natal University Oral Documentation \& Research Centre 
Suzman, Susan M. 1994. "Names as Pointers: Zulu Personal Naming Practices." Language in Society 23:253-72.

Thipa H. 1994. Sociolinguistics and Xhosa Names (Unpublished paper delivered at the 1st World Congress of African Linguistics, Univ. of Swaziland). 